\title{
Optimasi Cluster Pada Fuzzy C-Means Menggunakan Algoritma Genetika Untuk Menentukan Nilai Akhir
}

\author{
Putri Elfa Mas `udia*1 ${ }^{1}$, Retantyo Wardoyo ${ }^{2}$ \\ ${ }^{1}$ Universitas Muhammadiyah Malang; Jl. Raya Tlogomas 246, Malang, (0341) 463513 \\ ${ }^{2}$ Jurusan Ilmu Komputer dan Elektronika, FMIPA UGM, Yogyakarta \\ e-mail: *11aishsalma@gmail.com, ${ }^{2}$ rw@ugm.ac.id
}

\begin{abstract}
Abstrak
Nilai akhir mahasiswa dapat ditentukan dengan berbagai cara, beberapa diantaranya menggunakan range nilai, standart deviasi, dll. Dalam penelitian ini akan ditawarkan sebuah metode baru untuk menentukan nilai akhir mahasiswa menggunakan clustering dalam hal ini adalah Fuzzy C-Means.

Fuzzy C-Means digunakan untuk mengelompokkan sejumlah data dalam beberapa cluster. Tiap data memiliki derajat keanggotaan pada masing-masing cluster antara 0-1 yang diukur melalui fungsi objektif. Pada Fuzzy C-Means ini fungsi objektif diminimumkan menggunakan iterasi yang biasanya terjebak dalam optimum lokal. Algoritma genetika diharapkan dapat menangani masalah tersebut karena algoritma genetika berbasis evolusi yaitu dapat mencari individu terbaik melalui operasi genetika (seleksi, crossover, mutasi) dan dievaluasi berdasarkan nilai fitness.

Penelitian ini bertujuan untuk mengoptimasi titik pusat cluster pada Fuzzy C-Means menggunakan algoritma genetika. Hasilnya, bahwa dengan menggunakan GFS didapatkan fungsi objektif yang lebih kecil daripada menggunakan FCM, walaupun membutuhkan waktu yang relative besar. Meskipun selisih antara FCM dan GFS tidak terlalu besar namun hal tersebut berpengaruh pada anggota cluster
\end{abstract}

Kata kunci-clustering, Fuzzy C-Means, algoritma genetika

\section{Abstract}

The final grade of students could be determined in various ways, some of which use a range of values, deviation standard, etc. In this study will be offered a new method for determining final grades of students by using the clustering method. In this research the clustering method that will be used is the Fuzzy C-Means (FCM).

Fuzzy C-Means is used to group a number of data in multiple clusters. Each data has a degree of membership (the range value of membership degree is 0-1). Membership degree is measured through the objective function. In Fuzzy C-Means, objective function is minimized by using iteration and is usually trapped in a local optimum. Genetic algorithm is expected to handle these problems. The operation of genetic algorithm based on evolution that is able to find the best individuals through genetic operations (selection, crossover and mutation) and evaluated based on fitness values.

This research aims to optimize the cluster center point of FCM by using genetic algorithms. The result of this research shows that by combining the Genetic Algorithm with FCM could obtained a smaller objective function than using FCM, although it takes longer in execution time. Although the difference of objective function that produced by FCM and FCMGenetic Algorithm combination is not too big each other, but it takes effect on the cluster members.

Keywords-clustering, fuzzy c-means, genetic algorithm 


\section{PENDAHULUAN}

$\mathrm{T}$ erdapat berbagai cara untuk menentukan nilai akhir huruf mahasiswa, diantaranya adalah menggunakan skala pasti maupun standar deviasi, Tapi dengan cara yang seperti itu mungkin akan menyulitkan dosen jika terjadi kondisi-kondisi tertentu yang memerlukan pertimbangan dosen, pada sistem ini ditawarkan alternatif baru untuk penilaian dimana dosen diberi kebebasan (hak istimewa) untuk menentukan standart nilai menggunakan metode clustering dalam hal ini menggunakan fuzzy clustering. Cluster adalah sekelompok sesuatu yang mempunyai kesamaan sifat [1]. Fuzzy clustering memainkan peran yang paling penting dalam pencarian struktur dalam data [2].

Metode ini dipilih karena dengan metode ini, bisa ditentukan jumlah cluster yang akan dibentuk. Dengan penentuan jumlah cluster di awal, bisa diatur keragaman nilai akhir atau pelabelan nilai sesuai dengan clusternya.

Pada fuzzy c-means nilai awal titik pusat cluster dibangkitkan secara acak sehingga terjadi optimum lokal,dimana proses selanjutnya bergantung pada nilai awal yang dibangkitkan secara acak, disini akan digunakan algoritma genetika untuk mengoptimasi nilai awal titik pusat cluster.

Algoritma genetika (GA) sebagai teknik optimasi dapat diterapkan pada clustering yang berbasis optimasi fungsi tujuan. Pada pendekatan GA untuk fuzzy clustering fungsi fitness diambil dari fungsi objektif yang diminimumkan, yaitu $\operatorname{Jm}(\mathrm{U}, \mathrm{V})[3]$.

Pada pendekatan algoritma genetika, Pada setiap generasi, kromosom dievaluasi berdasarkan nilai fungsi fitness [4], untuk pencarian titik pusat cluster dilakukan dengan cara meng-evolusikan matrik pusat cluster (seleksi, crossover dan mutasi)dengan fungsi fitness menggunakan fungsi objektif yang terdapat pada fuzzy c-means

\section{METODE PENELITIAN}

Secara umum sistem yang akan dibuat dalam penelitian ini adalah sistem untuk menentukan nilai akhir huruf mahasiswa dengan menggunakan perhitungan Fuzzy clustering dan algoritma genetika dimana algoritma genetika digunakan untuk optimasi titik pusat cluster pada Fuzzy C-means.

Dengan menggunakan algoritma genetika, nilai awal titik pusat cluster $\mathrm{V}$ dibangkitkan secara acak, kemudian nilai $\mathrm{V}$ tersebut digunakan untuk menghitung matriks $u$. Selanjutnya nilai $\mathrm{V}$ ini akan dievolusikan menggunakan seleksi, crossover dan mutasi untuk mendapatkan nilai V yang paling optimum. Deskripsi umum sistem tersebut ditunjukkan pada Gambar 1

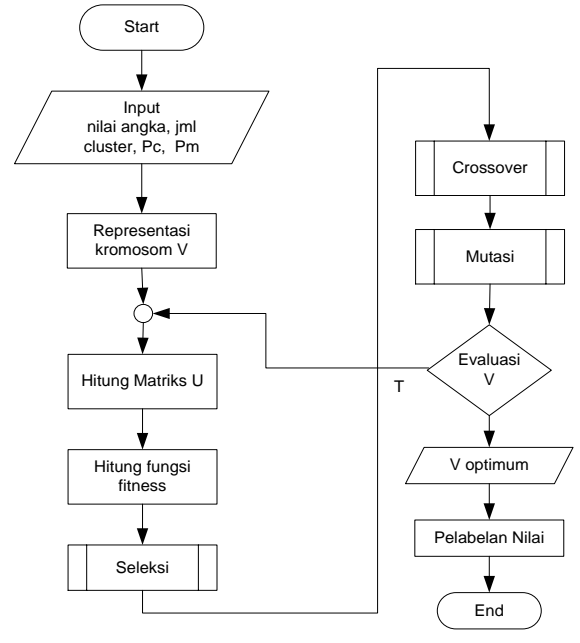

Gambar 1. Gambaran Umum Sistem

IJCCS Vol. 6, No. 1, January 2012: $101-110$ 
Langkah-langkah kegiatan yang akan dilakukan untuk permasalahan ini adalah:

1. Representasi solusi dan spesifikasi masukan dan keluaran.

2. Penentuan ukuran parameter genetika meliputi ukuran populasi, jumlah generasi, probabilitas crossover, probabilitas mutasi, maxIterasi.

3. Menentukan fungsi fitness yang digunakan, dalam hal ini fungsi fitness yang digunakan adalah fungsi objektif yang meminimumkan jarak antar data dengan titik pusat cluster (V) yang terdapat pada Fuzzy C-means.

4. Menentukan encoding kromosom yang digunakan yaitu real encoding.

5. Pemilihan fungsi seleksi yaitu menggunakan metode rank, crossover menggunakan one cut point, dan mutasi dengan mengubah gen secara acak.

6. Melakukan pengupdatetan matriks $u$ yang merupakan derajat keanggotaan data pada masing-masing titik pusat cluster $(\mathrm{V})$.

Langkah-langkah tersebut direpresentasikan pada Gambar 2.

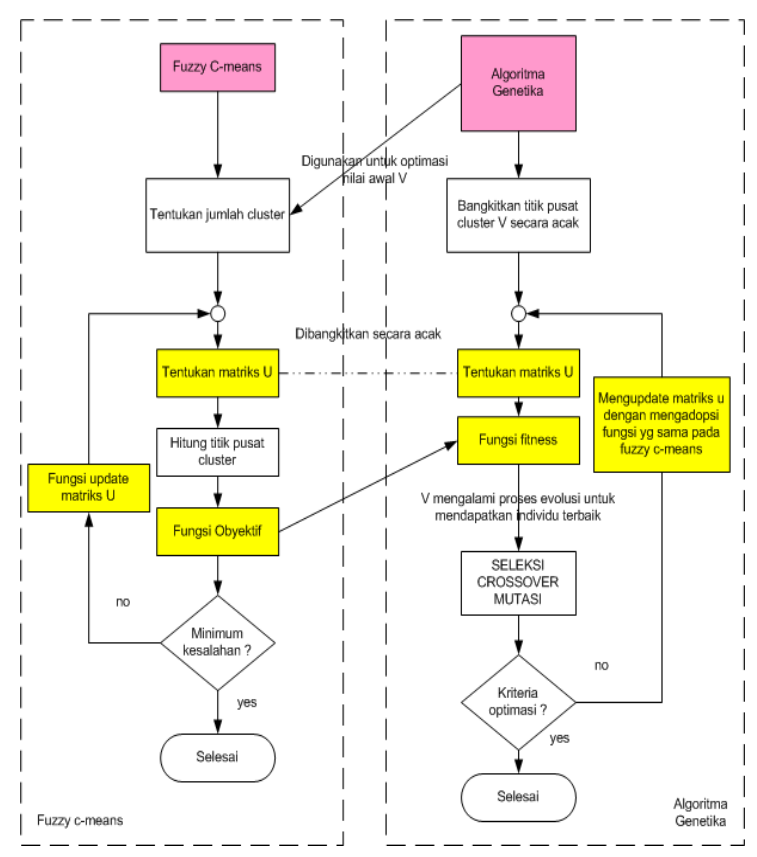

Gambar 2. Penerapan Algoritma Genetika pada Fuzzy C-means

\subsection{Perancangan Sistem}

Pada penelitian ini digunakan metode GFS (Genetic Fuzzy System) untuk menentukan nilai akhir kuliah mahasiswa. Dari data nilai mahasiswa akan dikelompokkan menjadi beberapa cluster, dalam hal ini dosen berhak menentukan jumlah cluster yang diinginkan berdasarkan nilai terendah dan nilai tertinggi pada data nilai mahasiswa. Kemudian dari hasil cluster yang didapatkan, dosen dapat memberi pelabelan nilai yang sesuai

Dalam clustering, persoalan sebenarnya adalah persoalan untuk mencari titik pusat cluster yang paling optimum berdasarkan fungsi objektif. Pada penelitian ini, persoalan ini akan diselesaikan dengan menggunakan algoritma genetika. Dalam algoritma genetika, solusi dari persoalan direpresentasikan dengan kromosom.

\section{1.1 Representasi Kromosom}

Pada penelitian ini nilai awal kromosom akan dibangkitkan secara acak sebanyak $\mathrm{n}$ cluster (V) dan sebanyak jumlah populasi kromosom m. Jadi satu gen mewakili satu cluster. Banyaknya jumlah cluster ditentukan oleh dosen berdasarkan nilai minimal dan maksimal dari 
data nilai mahasiswa, sedangkan jumlah awal kromosom yang digunakan pada penelitian ini adalah 50, hal ini dikarenakan algoritma genetika membutuhkan ruang solusi yang cukup besar dan ini berdasarkan rekomendasi dari De Jong 1975 yang terdapat pada dasar teori.

Tabel 1. Contoh Representasi Kromosom

\begin{tabular}{|c|c|c|c|c|c|c|}
\hline & $\mathrm{v} 1$ & $\mathrm{v} 2$ & $\mathrm{v} 3$ & $\mathrm{v} 4$ & $\cdots$ & $\mathrm{vn}$ \\
\hline Kromosom 1 & 1.4 & 5.0 & 7.1 & 1.5 & $\cdots$ & 0.4 \\
\hline Kromosom 2 & 0.5 & 4.4 & 6.0 & 1.3 & $\cdots$ & 2.6 \\
\hline$\ldots$ & $\cdots$ & $\cdots$ & $\cdots$ & $\cdots$ & $\cdots$ & $\cdots$ \\
\hline $\begin{array}{c}\text { Kromosom } \\
\mathrm{m}\end{array}$ & 1.7 & 2.1 & 6.3 & 5.5 & $\cdots$ & 2.7 \\
\hline
\end{tabular}

\subsubsection{Hitung Matrik $U$}

Matriks u adalah derajat keanggotaan data pada tiap-tiap cluster, Berdasarkan rumus perhitungan matriks u membutuhkan input berupa data nilai dan nilai titik pusat cluster. Rumus untuk menghitung matriks u ditunjukkan pada Rumus 1

$$
\mu_{i k}=\frac{\left[\sum_{i=1}^{m}\left(x_{i j}-V_{k i}\right)^{2}\right]^{\frac{-1}{w-1}}}{\sum_{k=1}^{c}\left[\sum_{i=1}^{m}\left(X_{i j}-V_{k i}\right)^{2}\right]^{\frac{-1}{w-1}}}
$$

\section{1.3 Fungsi Fitness}

Fungsi fitness merupakan ukuran kinerja suatu individu agar tetap bertahan hidup dalam lingkungannya. Dalam algoritma genetika fungsi fitness adalah fungsi objektif dari masalah yang akan dioptimasi.

Fungsi fitness yang digunakan dalam penelitian ini mengadopsi rumus fungsi objektif yang terdapat pada Fuzzy C-means yang meminimumkan jarak antara data dengan titik pusat cluster. Rumus fungsi objektif yang digunakan dalam fungsi fitness ditunjukkan pada Rumus 2

$$
\mathrm{P}_{\mathrm{t}}=\sum_{\mathrm{i}=1}^{\mathrm{n}} \sum_{\mathrm{k}=1}^{\mathrm{c}}\left(\left[\sum_{\mathrm{i}=1}^{\mathrm{m}}\left(\mathrm{X}_{\mathrm{ij}}-\mathrm{V}_{\mathrm{ki}}\right)^{2}\right]\left(\mu_{\mathrm{ik}}\right)^{\mathrm{w}}\right)
$$

\subsubsection{Seleksi}

Pada penelitian ini, seleksi kromosom dilakukan dengan menggunakan metode rank yang bertujuan untuk mendapatkan prosentase yang lebih merata. Seleksi ini menggunakan fitness skala dalam memilih kromosom dari populasi. Untuk menghitung fitness skala dari suatu kromosom, maka perlu diketahui terlebih dahulu jumlah seluruh fitness dalam populasi. Prosedur seleksi adalah sebagai berikut:

1. Menghitung nilai fitness $\left(f_{k}\right)$ tiap kromosom

2. Urutkan nilai fitness secara descending menggunakan library value comparator.

3. Beri prosentase pada tiap kromosom dengan membagi tiap kromosom dengan jumlah total kromosom dikalikan $100 \%$

4. Hitung akumulasi prosentase

5. Pilih induk yang menjadi kandidat untuk di-crossover dengan cara:

IJCCS Vol. 6, No. 1, January 2012: $101-110$ 
a. Bangkitkan suatu bilangan $[0,1]$

b. Memilih kromosom dengan nilai kumulatif $q_{k}$ yang lebih besar dan yang paling mendekati dari nilai random sebagai parent.

6. Lakukan langkah 5 sebanyak ukuran populasi.

\subsubsection{Crossover}

Metode crossover yang digunakan pada penelitian ini adalah metode one cut point karena mudah diterapkan pada kromosom yang diencodingkan secara real. Tidak semua kromosom mengalami crossover, kromosom yang di crossover sesuai dengan probabilitas crossover $(\mathrm{Pc})$. Jika terdapat dua kromosom yang nilai randomnya lebih kecil dari Pc, maka langsung di crossover, jika lebih dari dua kromosom maka dicrossover secara berurutan dan hanya dipilih satu offspring terbaik yang dapat menggantikan induk.

Prosedur persilangan satu titik sebagai berikut:

1. Menentukan Pc dan nilai acak $\mathrm{p}$, dimana $\mathrm{Pc}$ adalah peluang crossover dan $\mathrm{p}$ adalah nilai yang dibangkitkan secara acak. Hanya p yang lebih kecil dari Pc yang akan di crossover. Nilai awal Pc yang digunakan pada penelitian ini adalah 0,6 yang merupakan rekomendasi dari De jong yang mengacu pada dasar teori pada Bab III

2. Tentukan posisi crossover dengan cara membangkitkan bilangan acak dengan batasan 1 sampai $\mathrm{n}-1$, dimana $\mathrm{n}$ adalah panjang kromosom. Misalkan didapat posisi crossover adalah 20 maka kromosom induk akan dipotong mulai gen ke 21 sampai gen ke n, kemudian potongan gen tersebut saling ditukar antar induk.

3. Posisi cut-point crossover dipilih menggunakan bilangan acak 1-(n-1) sebanyak jumlah crossover yang terjadi.

\subsubsection{Mutasi}

Metode mutasi dilakukan dengan cara uniform, yaitu dengan mengganti satu gen yang dipilih secara acak dengan suatu nilai baru dalam hal ini nilai baru tersebut juga ditentukan secara acak. Jumlah kromosom yang mengalami mutasi dalam satu populasi ditentukan oleh parameter peluang mutasi $\left(p_{m}\right)$.

Langkah-langkah mutasi sebagai berikut:

1. Menentukan Pm dan $\mathrm{p}$, dimana $\mathrm{Pm}$ adalah peluang mutasi dan $\mathrm{p}$ adalah nilai yang dibangkitkan secara acak. Nilai awal Pm yang digunakan pada penelitian ini adalah 0,001 yang merupakan rekomendasi dari De jong yang mengacu pada dasar teori yang terdapat pada Bab III

2. Untuk memilih posisi gen yang akan mengalami mutasi dilakukan dengan cara membangkitkan bilangan acak (p) antara 0 sampai 1 . Jika $\mathrm{p}<p_{m}$, maka gen akan dimutasi, misal $p_{m}$ kita temukan $10 \%$ maka diharapkan ada $10 \%$ dari populasi yang mengalami mutasi.

3. Bangkitkan bilangan acak untuk mengubah nilai gen yang ditentukan secara acak dengan nilai yang acak.

\section{HASIL DAN PEMBAHASAN}

Pembahasan pada sistem ini meliputi perbandingan clustering menggunakan FCM dan GFS dilihat dari nilai objektif, hasil pengelompokan data, waktu dan analisis pengaruh parameter genetika terhadap nilai objektif dan lama proses sistem. Pengaruh parameter yang dipelajari dalam penelitian ini dikelompokkan menjadi 4 bagian yaitu:

1. Hasil clustering menggunakan FCM

2. Pengaruh parameter ukuran populasi.

3. Pengaruh parameter jumlah iterasi

4. Pengaruh kombinasi parameter Pc dan Pm

$\overline{\text { Optimasi Cluster Pada FCM Menggunakan GA Untuk Menentukan Nilai Akhir (Putri Elfa M.) }}$ 


\subsection{Hasil Percobaan}

Hasil percobaan pertama adalah hasil clustering dengan menggunakan parameter popsize, $\mathrm{Pc}, \mathrm{Pm}$ rekomendasi dari De jong, yaitu populasi $=50, \mathrm{Pc}=0,6, \mathrm{Pm}=0,001$, maksimal iterasi $=100$ dan jumlah cluster $=4$ Data tersebut ditampilkan dalam Tabel 2 berikut ini.

Tabel 2 Data Nilai Mahasiswa Percobaan 1

\begin{tabular}{||l||l||l|l|l|l||}
\hline Nim & Nama & Nilai & Cluster & Pusat Cluster & Nilai Huruf \\
\hline 1031140052 & Aditya Dani Rosanto & 90.0 & 4 & 94.11973 & A \\
\hline 1031140065 & Adhi Susanto & 72.0 & 2 & 73.054245 & B \\
\hline 1031140003 & Arynda Putri Mertabuan & 35.0 & 3 & 24.373365 & D \\
\hline 1031140099 & Avinda Ika Nadiasari & 25.0 & 3 & 24.373365 & D \\
\hline \hline 1031140059 & Bagus Rakhmadian & 63.0 & 1 & 73.054245 & C \\
\hline 1031140009 & Deka Cahya Endradewi & 83.0 & 2 & 73.054245 & B \\
\hline \hline 1031140056 & Dian Munika Ayu & 44.0 & 1 & 48.716026 & C \\
\hline \hline 1031140083 & Diana Mayangsari & 10.0 & 3 & 24.373365 & D \\
\hline \hline 1031140076 & Elviera Savitrie P & 53.0 & 1 & 48.716026 & C \\
\hline \hline 1031140024 & Farah Azizah Ansi & 95.0 & 4 & 94.11973 & A \\
\hline 1031140092 & Firman Adiyansyah & 80.0 & 2 & 73.054245 & B \\
\hline 1031140041 & Ira Reza Permata & 75.0 & 2 & 73.054245 & B \\
\hline \hline 1031140072 & M. Hamzah Mashuri & 65.0 & 1 & 73.054245 & C \\
\hline \hline 1031140066 & Madarina Imanisari & 95.0 & 4 & 94.11973 & A \\
\hline \hline 1031140097 & Mokh Zafril & 51.0 & 1 & 48.716026 & C \\
\hline \hline 1031140033 & Nadia Putri & 50.0 & 1 & 48.716026 & C \\
\hline \hline 1031140046 & Putri Ardiani & 25.0 & 3 & 24.373365 & D \\
\hline \hline 1031140017 & Raj Nur & 45.0 & 1 & 48.716026 & C \\
\hline \hline 1031140045 & Revidya Dewantari & 75.0 & 2 & 73.054245 & B \\
\hline \hline 1031140022 & RR Eka Regina & 100.0 & 4 & 94.11973 & A \\
\hline \hline
\end{tabular}

Dari hasil yang ditunjukkan pada Tabel 6.1, didapatkan fungsi objektif sebesar 800,557 dan membutuhkan waktu $869 \mathrm{~ms}$

Percobaan selanjutnya sistem dijalankan dengan menggunakan data parameter genetika dengan jumlah cluster yang sama, tetapi parameter berbeda. Jumlah cluster $=4$, ukuran populasi 50, probabilitas crossover $(\mathrm{Pc}) 0.3$, probabilitas mutasi $(\mathrm{Pm})$ 0.9, pembobot 2 dan max iterasi 300.

Tabel 3. Data Nilai Mahasiswa Percobaan 2

\begin{tabular}{|c|c|c|c|c|c|}
\hline Nim & Nama & Nilai & Cluster & Pusat Cluster & Nilai Huruf \\
\hline 1031140052 & Aditya Dani Rosanto & 90.0 & 2 & 94.11973 & $A$ \\
\hline 1031140065 & Adhi Susanto & 72.0 & 3 & 73.054245 & $B$ \\
\hline 1031140003 & Arynda Putri Mertabuan & 35.0 & 4 & 24.373365 & D \\
\hline 1031140099 & Avinda Ika Nadiasari & 25.0 & 4 & 24.373365 & D \\
\hline |1031140059 & Bagus Rakhmadian & 63.0 & $\mid 3$ & 73.054245 & B \\
\hline 1031140009 & Deka Cahya Endradewi & 83.0 & 3 & 73.054245 & B \\
\hline 1031140056 & Dian Munika Ayu & 44.0 & 1 & 48.716026 & C \\
\hline 1031140083 & Diana Mayangsari & 10.0 & 4 & 24.373365 & $D$ \\
\hline 1031140076 & Elviera Savitrie P & 53.0 & $\mid 1$ & 48.716026 & C \\
\hline 1031140024 & Farah Azizah Ansi & 95.0 & 2 & 94.11973 & $A$ \\
\hline 1031140092 & Firman Adiyansyah & 80.0 & 3 & 73.054245 & $B$ \\
\hline 1031140041 & Ira Reza Permata & 75.0 & 3 & 73.054245 & $B$ \\
\hline 1031140072 & M. Hamzah Mashuri & 65.0 & 3 & 73.054245 & $B$ \\
\hline |1031140066 & Madarina Imanisari & 95.0 & 2 & 94.11973 & A \\
\hline 1031140097 & Mokh Zafril & 51.0 & 1 & 48.716026 & C \\
\hline 1031140033 & Nadia Putri & 50.0 & 1 & 48.716026 & C \\
\hline 1031140046 & PutriArdiani & 25.0 & 4 & 24.373365 & $D$ \\
\hline 1031140017 & Raj Nur & 45.0 & 1 & 48.716026 & C \\
\hline 1031140045 & Revidya Dewantari & 75.0 & 3 & 73.054245 & $B$ \\
\hline 1031140022 & RR Eka Regina & 100.0 & 2 & 94.11973 & A \\
\hline
\end{tabular}

IJCCS Vol. 6, No. 1, January 2012: $101-110$ 
Dari hasil percobaan tersebut terlihat sedikit perbedaan pengelompokkan nilai. Fungsi objektif terakhir yang dihasilkan pada percobaan kedua adalah 662.817 dan membutuhkan waktu $2795 \mathrm{~ms}$, nilai ini jauh lebih baik dibandingkan percobaan sebelumnya, data inilah yang digunakan sebagai acuan untuk membandingkan hasilnya dengan metode FCM.

\subsection{Hasil Perbandingan dengan FCM}

Dilakukan perbandingan menggunakan FCM dan GFS dengan data yang sama dan jumlah cluster yang sama.Metode GFS dijalankan dengan menggunakan data parameter genetika dengan jumlah cluster $=4$, ukuran populasi 50, probabilitas crossover $(\mathrm{Pc}) 0.3$, probabilitas mutasi (Pm) 0.9, pembobot 2 dan max iterasi 300. Data ini ditentukan secara acak. Fungsi objektif terakhir yang dihasilkan adalah 662.817 dan membutuhkan waktu 2795 ms.

Pengelompokan data nilai mahasiswa menggunakan FCM (Fuzzy C-Means) dilakukan dengan nilai parameter jumlah cluster $=4$, pembobot $=2$, maxIterasi $=100$. Dari percobaan tersebut diketahui bahwa hasil cluster data nilai mahasiswa hasilnya sama baik menggunakan FCM maupun GFS, sedangkan dilihat dari waktu yang digunakan untuk mengklaster data, FCM relative lebih singkat disbanding GFS.

Fungsi objektif yang dihasilkan FCM lebih besar dari GFS yaitu 662.82, hal ini dikarenakan proses penyelesaian optimasi secara klasik sering menghantar pada penyelesaian yang merupakan optimum lokal sedangkan algoritma genetika akan selalu berevolusi untuk menemukan individu yang lebih baik tergantung dari parameter masukan.

\subsection{Pengaruh Parameter Ukuran Populasi}

Percobaan pertama adalah dengan mengambil jumlah cluster $=4$, ukuran populasi $=10$, $\mathrm{Pc}=0.4$, dan $\mathrm{Pm}=0.8$, jumlah iterasi $=100$. Satu nilai parameter yang sama dihitung sebanyak 5 kali. Percobaan selanjutnya adalah dengan menambah ukuran populasi dan tetap menggunakan nilai parameter yang sama seperti pada percobaan pertama. Setelah dilakukan 10 kali percobaan dengan ukuran populasi yang berbeda diperoleh hasil seperti Tabel2

Tabel 4 Pengaruh Parameter Ukuran Populasi

\begin{tabular}{|c|c|c|c|c|c|}
\hline $\begin{array}{l}\text { Ukuran } \\
\text { Populasi }\end{array}$ & Nilai Objektif $(B)$ & $\begin{array}{c}\text { Waktu } \\
\text { Proses } \\
(\mathrm{ms})\end{array}$ & $\begin{array}{c}\text { Ukuran } \\
\text { Populasi }\end{array}$ & $\begin{array}{c}\text { Nilai } \\
\text { Objektif } \\
(B)\end{array}$ & $\begin{array}{c}\text { Waktu } \\
\text { Proses (ms) }\end{array}$ \\
\hline \multirow[t]{5}{*}{10} & 682,817 & 188 & \multirow[t]{5}{*}{50} & 663,330 & 1058 \\
\hline & 753,889 & 188 & & 670,899 & 1035 \\
\hline & 668,92 & 186 & & 663,210 & 1162 \\
\hline & 678,316 & 191 & & 665,880 & 933 \\
\hline & 674,107 & 190 & & 664,535 & 1079 \\
\hline \multirow[t]{5}{*}{20} & 674,643 & 374 & \multirow[t]{5}{*}{80} & 662,889 & 1822 \\
\hline & 667,502 & 458 & & 663,540 & 1740 \\
\hline & 666,024 & 382 & & 663,730 & 1701 \\
\hline & 670,111 & 379 & & 663,880 & 1620 \\
\hline & 690,206 & 360 & & 663,117 & 1729 \\
\hline \multirow[t]{5}{*}{30} & 669,843 & 566 & \multirow[t]{5}{*}{100} & 663,09 & 2610 \\
\hline & 663,751 & 650 & & 663,089 & 2256 \\
\hline & 668,497 & 575 & & 663,477 & 2238 \\
\hline & 666,702 & 398 & & 662,997 & 2265 \\
\hline & 667,801 & 450 & & 663,137 & 2647 \\
\hline \multirow[t]{5}{*}{40} & 667,162 & 779 & \multirow[t]{5}{*}{150} & 662,879 & 3406 \\
\hline & 671,35 & 772 & & 662,861 & 3505 \\
\hline & 664,501 & 820 & & 662,863 & 3762 \\
\hline & 676,153 & 726 & & 663,070 & 3065 \\
\hline & 665,313 & 650 & & 662,910 & 3889 \\
\hline
\end{tabular}

Dari tabel diatas dapat dilihat bahwa semakin besar jumlah populasi maka nilai objektifnya semakin kecil dan stabil dan membutuhkan waktu yang relative lebih besar. Hal ini dikarenakan semakin banyak jumlah populasi kemungkinan ruang solusi juga semakin besar 
dan peluang untuk memperoleh individu yang lebih baik semakin besar walaupun harus dibayar dengan waktu yang lebih banyak.

\subsection{Pengaruh Parameter Jumlah Iterasi}

Percobaan pertama adalah dengan mengambil jumlah iterasi awal $=100$, ukuran populasi $=50, \mathrm{Pc}=0.8$, dan $\mathrm{Pm}=0.2$. Percobaan selanjutnya adalah dengan menambah jumlah iterasi dan tetap menggunakan nilai parameter lain yang sama seperti pada percobaan pertama. Setelah dilakukan 8 kali percobaan diperoleh nilai objektif seperti Tabel 5

Tabel 5 Pengaruh Parameter Jumlah Iterasi

\begin{tabular}{|c|c|c|c|c|c|}
\hline $\begin{array}{l}\text { Jumlah } \\
\text { Iterasi }\end{array}$ & Nilai Objektif $(B)$ & $\begin{array}{c}\text { Waktu } \\
\text { Proses } \\
(\mathrm{ms})\end{array}$ & $\begin{array}{l}\text { Jumlah } \\
\text { Iterasi }\end{array}$ & $\begin{array}{c}\text { Nilai } \\
\text { Objektif } \\
(B)\end{array}$ & $\begin{array}{c}\text { Waktu } \\
\text { Proses (ms) }\end{array}$ \\
\hline \multirow[t]{5}{*}{50} & 664,692 & 535 & \multirow[t]{5}{*}{400} & 662,911 & 3264 \\
\hline & 667,569 & 552 & & 662,830 & 3113 \\
\hline & 675,553 & 449 & & 662,901 & 3963 \\
\hline & 681,370 & 412 & & 662,860 & 3888 \\
\hline & 670,824 & 474 & & 662,849 & 3246 \\
\hline \multirow[t]{5}{*}{100} & 667,04 & 1107 & \multirow[t]{5}{*}{500} & 662,839 & 4934 \\
\hline & 663,46 & 1111 & & 662,852 & 4068 \\
\hline & 664,091 & 1064 & & 662,817 & 4065 \\
\hline & 665,651 & 1079 & & 662,85 & 4474 \\
\hline & 663,920 & 1095 & & 662,833 & 4808 \\
\hline \multirow[t]{5}{*}{200} & 663,213 & 1735 & \multirow[t]{5}{*}{800} & 662,830 & 7331 \\
\hline & 663,240 & 1943 & & 662,827 & 6230 \\
\hline & 663,490 & 1909 & & 662,818 & 6505 \\
\hline & 663,831 & 1928 & & 662,817 & 7200 \\
\hline & 663,197 & 1934 & & 662,819 & 7730 \\
\hline \multirow[t]{5}{*}{300} & 662,970 & 2936 & \multirow[t]{5}{*}{1000} & 662,830 & 7819 \\
\hline & 662,890 & 2840 & & 662,818 & 8941 \\
\hline & 662,860 & 2808 & & 662,820 & 7556 \\
\hline & 662,88 & 2559 & & 662,818 & 7467 \\
\hline & 662,95 & 2728 & & 662,816 & 7556 \\
\hline
\end{tabular}

Dari Tabel 6.5 diketahui bahwa nilai objektif terbaik (yang lebih kecil daripada FCM) diperoleh mulai dari jumlah iterasi 500 dan seterusnya, dimana nilai objektif yang diperoleh yaitu 662,817. Perbedaan nilai yang terjadi pada iterasi yang sama dikarenakan setiap kali perhitungan yang berbeda, proses seleksi, crossover, dan mutasi yang terjadi juga berbeda tergantung bilangan acak yang didapatkan. Hasil ini bisa lebih baik maupun lebih buruk.

\subsection{Pengaruh Kombinasi Pc dan Pm}

Percobaan pertama adalah dengan mengambil nilai $\mathrm{Pc}=0.6$, dan $\mathrm{Pm}=0,001$ ukuran populasi $=50$, jumlah iterasi $=500$. Percobaan selanjutnya adalah dengan menambah nilai Pm dan tetap menggunakan nilai parameter lain yang sama seperti pada percobaan pertama kemudian dilanjutkan mengubah $\mathrm{Pc}=0,1$ dan seterusnya. Satu parameter dihitung sebanyak 3 kali

Hasil pengujian menunjukkan bahwa perubahan nilai Pm sangat berpengaruh pada hasil fungsi objektif dimana nilai Pm yang dapat menghasilkan fungsi objektif terbaik adalah antara 0,7- 0,9. Nilai parameter Pm yang cenderung besar ini menyebabkan jumlah kromosom baru hasil mutasi lebih banyak untuk generasi berikutnya sehingga nilai objektif terbaik akan mudah dicapai.

Untuk perubahan nilai Pc tidak terlalu berpengaruh secara signifikan pada hasil fungsi objektif, namun ketika kombinasi $\mathrm{Pc}=0,3$ dan $\mathrm{Pm}=0,9$ setelah 10 kali perhitungan semua hasil proses menghasilkan nilai objektif yang lebih rendah dari FCM. Hal ini dikarenakan parameter $\mathrm{Pc}=0,3$ tidak terlalu kecil tapi juga tidak besar.

IJCCS Vol. 6, No. 1, January 2012: $101-110$ 


\subsection{Perbandingan FCM dan GFS dengan Data Terperinci}

Percobaan selanjutnya dilakukan dengan mengubah-ubah data yang lebih presisi untuk menguji apakah fungsi objektif yang berbeda dengan selisih yang sangat kecil berpengaruh terhadap anggota cluster. Hal ini terbukti pada hasil yang diperoleh pada data 82,87 dimana fungsi objektif yang dihasilkan dari proses GA dan GFS berbeda dengan selisih 0,01. Fungsi objektif hasil proses FCM adalah 675,53 dan fungsi objektif hasil proses GFS adalah 675,527. Hasil percobaan diatas menunjukkan bahwa dengan selisih fungsi objektif yang kecil yaitu 0,01 dapat berpengaruh terhadap anggota cluster jika datanya adalah data yang lebih presisi (dengan beberapa angka dibelakang koma). Hal ini dikarenakan walaupun fungsi objektif hanya selisih 0,01 tapi hal tersebut berpengaruh terhadap titik pusat cluster. Data yang lebih terinci, akan membutuhkan ketelitian lebih untuk memilih anggota pada cluster.

Pada hasil proses FCM_GA data nilai 82,87 masuk ke cluster 4 dengan titik pusat cluster adalah 72,391 sedangkan hasil proses FCM, data nilai 82,87 masuk ke cluster 2 dengan titik pusat cluster adalah 93,359.

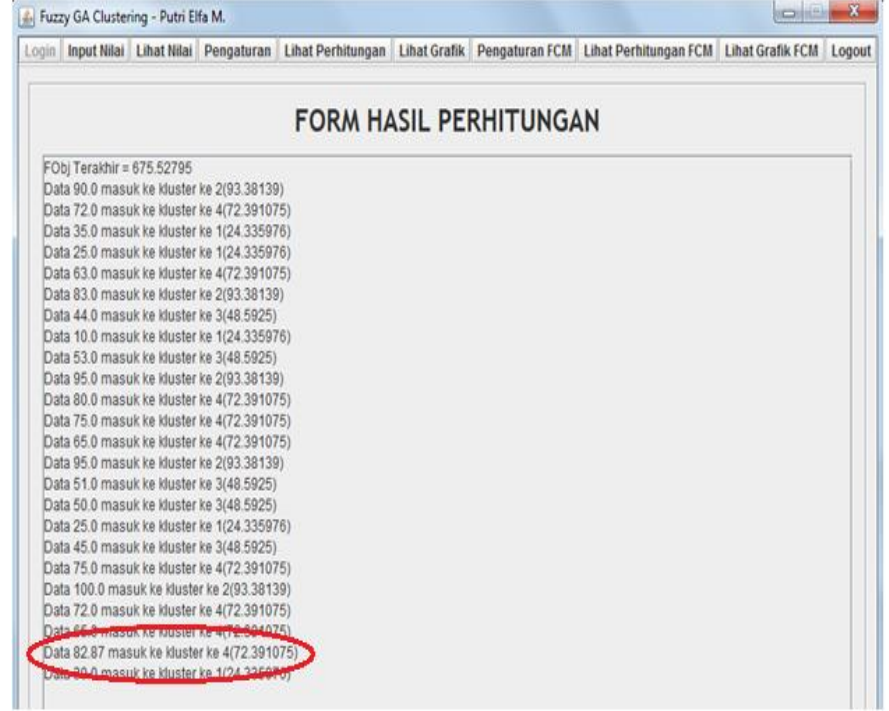

Gambar 3. Hasil Perhitungan GFS

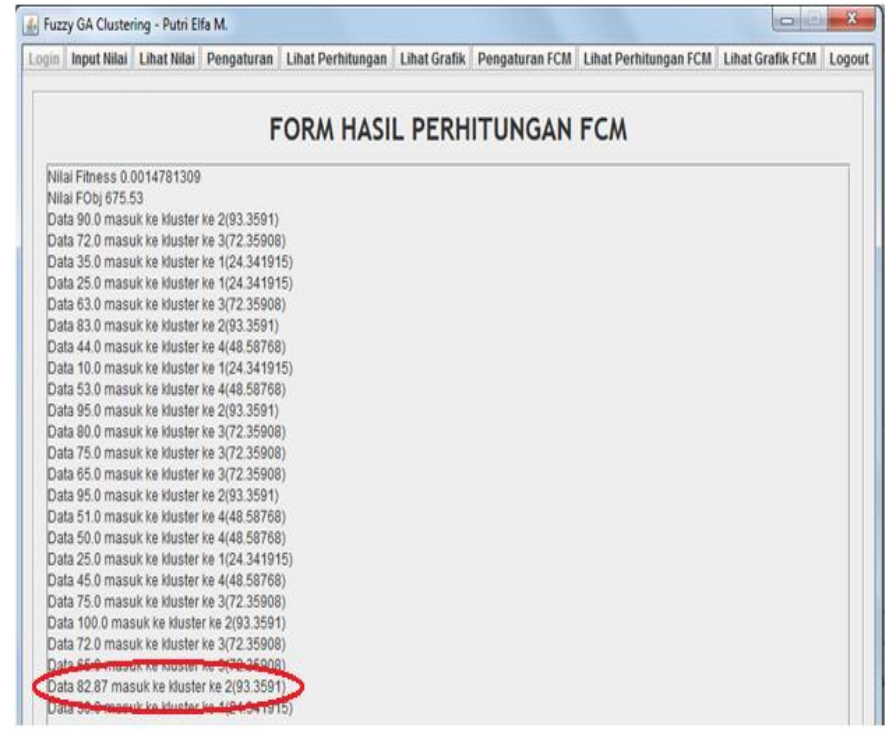

Gambar 4. Hasil Perhitungan FCM 


\section{KESIMPULAN}

1. Algoritma genetika (GFS) dapat digunakan untuk mengelompokkan data nilai mahasiswa dengan nilai fungsi objektif yang lebih kecil daripada menggunakan FCM.

2. Meskipun selisih nilai objektif hasil proses GFS dan FCM tidak terlalu besar tetapi hal tersebut berpengaruh terhadap keanggotaan pada tiap-tiap cluster karena data yang lebih terperinci (beberapa dibelakang koma) membutuhkan ketelitian tinggi untuk memilih anggota cluster.

3. Setiap dilakukan beberapa kali perhitungan pada parameter genetika yang sama, hasilnya bisa berubah-ubah karena setiap kali perhitungan, proses seleksi, crossover dan mutasi yang terjadi juga berbeda. Namun pada kombinasi Pc 0,3 dan Pm 0,9 perubahan yang terjadi sangat kecil dan relative stabil.

4. Jika ditinjau dari waktu komputasi, metode GFS masih relative membutuhkan waktu yang lebih lama dibanding menggunakan FCM karena untuk menemukan individu terbaik menggunakan proses evolusi (seleksi, crossover, mutasi) yang membutuhkan waktu lebih besar daripada FCM yang hanya meminimumkan jarak dengan menggunakan iterasi. Namun dengan perkembangan prosesor yang semakin baik kemungkinan hal tersebut dapat diatasi.

5. Semakin besar ukuran populasi dan jumlah iterasi maka hasil yang didapatkan akan semakin optimal dan stabil, stabil dalam artian nilai objektif relatif sama meskipun dilakukan beberapa kali perhitungan. karena semakin banyak jumlah generasi maka memberikan eksplorasi terhadap ruang pencarian yang lebih besar walaupun harus dibayar dengan waktu yang lebih lama.

\section{SARAN}

Berdasarkan pada pengujian yang telah dilakukan pada sistem yang dibuat, masih banyak kekurangan dan kelemahan sehingga perlu dikembangkan lagi agar kinerjanya lebih baik, oleh karena itu saran yang diberikan adalah sebagai berikut:

1. Metode GFS ini lebih baik digunakan untuk studi kasus yang membutuhkan data yang lebih presisi, misalnya pengukuran yang membutuhkan tingkat ketelitian yang tinggi.

2. Pada penelitian lebih lanjut diharapkan melakukan riset algoritma untuk mengoptimalkan nilai parameter Pc dan Pm sehingga didapatkan nilai Pc dan Pm yang terbaik yang dapat digunakan pada berbagai jenis data yang berbeda.

\section{DAFTAR PUSTAKA}

[1] Cox, E. 2005. Fuzzy Modeling and Genetic Algorithm for Data Mining and Exploration, Morgan Kaufmann Publisher, San Francisco.

[2] Klir G. J., Yuan B., 1995. Fuzzy Sets and Fuzzy Logic, Theory and Application. Prentice Hall International, Inc.

[3] Widyastuti N., Hamzah A., 2007, Penggunaan Algoritma Genetika Dalam Peningkatan Kinerja Fuzzy Clustering untuk Pengenalan Pola, Seminar Penggunaan Algoritma Genetika, Yogyakarta

[4] Gen, M. and Cheng, R., 2000, Genetic Algorithms and Engineering Optimization, John Wiley \& Sons, New York.

IJCCS Vol. 6, No. 1, January 2012: $101-110$ 